\title{
Structured Approach to Enhance the Quality of Undergraduate Capstone Project: A Case Study
}

\author{
Rajendra Pawar ${ }^{1}$, Sachin Patil ${ }^{2}$ \\ ${ }^{1}$ Assistant Professor, Department of Mechanical Engineering, \\ ${ }^{2}$ Associate Professor, Department of Mechanical Engineering, \\ K. E. Society's Rajarambapu Institute of Technology, Rajaramnagar. Affiliated to Shivaji University Kolhapur, Maharashtra, \\ India \\ ${ }^{1}$ rajendra.pawar@ritindia.edu \\ ${ }^{2}$ sachink.patil@ ritindia.edu
}

\begin{abstract}
:
The capstone project course has been considered as a commanding student-centered learning activity designed to provide an opportunity to an undergraduate student to solve critical real-life problems by applying the technical and soft skills acquired. A major objective of the capstone project is to apply real-life engineering practices to fulfill customer needs. This paper outline the challenges and best practices learned in the development and implementation of the open-ended undergraduate capstone project with the intention to enhance the quality and learning outcomes. In order to enhance the quality of the capstone project, various strategies such as group formation, student evaluation, sourcing student projects, project plan, project space, project funding, and support for patent and paper publications have been discussed also. The capstone project is offered in the fourth year of B. Tech. mechanical engineering program and it consists of two modules; Phase I and Phase II. Around 72 students and 18 supervisors were involved in the activity for the entire academic year. The student learning outcomes were measured using the commercial software and observed that all the learning outcomes have been attained more than $75 \%$ and students have developed very good projects in a team by applying technical knowledge and soft skills learned in the program.
\end{abstract}

\footnotetext{
Rajendra Pawar

Assistant Professor, Department of Mechanical Engineering

K. E. Society's Rajarambapu Institute of Technology, Rajaramnagar. Affiliated to Shivaji University Kolhapur, Maharashtra, India

rajendra.pawar@ritindia.edu
}

Keywords: Course Outcomes; Capstone Project; Engineering Education; Evaluation Rubrics; Mechanical engineering

\section{Introduction}

Nowadays engineering education calls for innovative and creative ways of preparing students for the future industrial revolution. Engineering education is a continuously developing process that depends on industrial demand. Always it finds new strategies, plans, and technologies to produce well-integrated next-generation engineers with professional competencies (Rajendra Pawar et al. 2020). Engineering education plays a significant role in the development of future students, where the student should have the ability to tackle real-life problems. The capstone project is one of the course where the final year students are getting the chance to work with real-life problems. The capstone project is a yearlong process in which final year undergraduate students works on the industrial and societal problems of their choice under the guidance of the faculty supervisor and produces the substantial documents/report that reflects the deep understanding of the topic. The general principle behind outcomes-based education is that it shifts the focus of curricula from an instructor-centered to a student-centered domain (Rajendra Pawar et al. 2020).

The capstone project involves the identification of realworld problems and the application of the technical skills and methods learned to develop the solution. The capstone project is a valuable practical experience where a student can explore the research, analytical, experimental, communication, and writing skills. The capstone project course is based on both technical knowledge and the soft skills acquired in earlier courses of undergraduate and it provides the design, develop and test experience in the $\mathrm{B}$. Tech. curriculum. It is an open-ended opportunity for the student to apply the engineering learning to real-life industry-oriented problems and also provides the important components for student outcome assessment (S. Howe, 2017). A capstone project is a kind of hands-on training platform where students apply the fundamentals of engineering and sciences, seek new knowledge, develop an ability to work in a team, analyze an open-ended problem 
with design alternatives, and create documentation. The individual student learning of the capstone project is assessed using various methods.

Mohamed A. Omar (2014) has implemented virtual product development tools for an undergraduate mechanical capstone design project to simulate the industrial environment through multidisciplinary teams with a focus on class organization, policies, and procedures. Kala Meah et al. (2020) has applied the multidisciplinary approach for the capstone project where students from mechanical, electrical, and computer engineering programs workes together to design, build, and test drive an electric vehicle and also focused on the management and assessment of student growth and learning in several critical ABET skills student needed during their careers. Manankilet al. (2016) has proposed a way to integrate knowledge and empower students to become change agents in the practice setting. Engaging in a capstone learning experience designed with the intent to help make a difference in clinical practice provided the students with an opportunity to rehearse their role as change agents in a practice setting. The experience gave students exposure to real-world, authentic practice setting issues, for which they developed creative solutions.

Jacqueline Stagner and Jennifer Johrendt, (2014) has presented the various techniques incorporated in the capstone design course to assess many of the CEAB graduate attributes and learning outcomes, and implement a continuous improvement program for the department. Continuous improvement is a necessary part of the course curriculum development and the assessment methods employed to measure learning outcomes achievement. Tien D.T.K., Mohyi M.H.H. (2016) has described the assessment strategy adopted for MEGP2 and provides key observations on the learning attainments made possible through it in achieving the modules and the conceivedesign-Implement-operate learning outcomes. The assessment process of the capstone module has an impact on students' learning experience.

Deepamala, N., and Shobha, G. (2018) have discussed the approach followed for three academic years 2014-2017 on a batch of 180 students per year. Training sessions, evaluation rubrics, usage of project management tools, mapping performance of the students with the outcomes of the course and program, feedback from the stakeholders like companies and students themselves give a clear view of improvement of the performance of the students during the final year capstone project course. The program can be improved through observations and actions taken based on the attainment of course outcomes and it provides a holistic approach to the learning experience of students through the capstone project.

Mosher, Gretchen A. (2014) outlined the challenges and best practices learned in the development and implementation of a senior-level capstone course in engineering technology, based on qualitative data gathered over several years. Specifically, strategies for sourcing student projects, student team formation and management, and options for ensuring accountability among student teams have a major impact on student learning. The fair and consistent assessment methods for group and individual work are the important factor for assessment of the student learning. Jon M. Duff and Thomas E. Schildgen (2005) has utilized a methodology for validating a senior project that included a descriptive survey of three constituent groups: students in upper-division courses, faculty, and a jury of senior industry advisory board members. Shekar Viswanathan (2017) has focused on three specific capstone projects that were worked in an undergraduate manufacturing design engineering program and summarized the design methodologies and strategies that were adopted by the students and faculty. Also, described how a capstone project in manufacturing design engineering should be designed for maximum effectiveness.

Ultimately, a capstone project represents new work and ideas and allows the student to demonstrate the knowledge and skills they have gained during the undergraduate program. Capstone projects also tend to encourage students to connect their projects to community issues or problems, and to integrate outside-of-school learning experiences. A structured approach implemented to enhance the quality of the final year undergraduate capstone project of the Mechanical Engineering Department of Rajarambapu Institute of Technology, Rajaramnagar is presented in this paper.

The capstone project consists of a two-course sequence in the $7^{\text {th }}$ and $8^{\text {th }}$ academic semesters: Capstone Phase I and Capstone Phase II. However, capstone courses also require students to focus on a variety of professional skills, including teamwork, unstructured task completion, and project management. The important facets of the capstone project course are

(i) Developing a strategic plan to guide the students to deliver quality project and engineering reports.

(ii) Continuous evaluation of individual student using assessment rubrics

(iii) Evaluate the learning outcomes by mapping evaluating rubrics with course outcomes.

(iv) Prepare an action plan to improve the quality of course by assessing the program outcomes mapped with course outcomes

(v) Feedback from the stockholder and assess the performance

The paper outlines the approach followed for the last three academic years $2017-2020$ on around 17 project groups in the development and implementation of a capstone project in engineering education, based on qualitative data gathered. The strategies for the student group assemblage, sourcing student projects, continuous assessment methods for group and individual work, mapping performance of the students 
with the outcomes of the course and program, and feedback from the student are also be emphasized. More focus is given to motivate and enable the individual student by taking their aspirations into account.

\section{Methodology}

Students studying in the fourth year of B. Tech. Mechanical Engineering is required to complete the two-semester $\left(7^{\text {th }}\right.$ and $8^{\text {th }}$ ) capstone project course. A capstone project is a twelve-credit, two-semester independent project performed under the close supervision of the capstone supervisor and it is designed to inspire the engineering students to solve real-life problems, think critically, generate innovative concepts, and develop skills such as communication, teamwork, project planning, report writing, self-sufficiency, or goal setting, etc. In some projects, an interdisciplinary approach is also applied, where students explore problems across many different subject areas or domains of knowledge. The capstone project consists of two modules; Project Phase I and Project Phase II as shown in Table 1.

Table 1. Capstone Project Modules

\begin{tabular}{|c|c|c|c|c|}
\hline \multirow{2}{*}{ Module } & \multirow{2}{*}{ Credits } & \multirow{2}{*}{$\begin{array}{c}\text { Contact } \\
\text { Hrs }\end{array}$} & \multicolumn{2}{|c|}{$\begin{array}{c}\text { Examination } \\
\text { Scheme }\end{array}$} \\
\cline { 4 - 5 } & & & ISE & ESE \\
\hline $\begin{array}{c}\text { Project } \\
\text { Phase I }\end{array}$ & 4 & 4 & $100 \%$ & -- \\
\hline $\begin{array}{c}\text { Project } \\
\text { Phase II }\end{array}$ & 8 & 8 & $50 \%$ & $50 \%$ \\
\hline
\end{tabular}

Initially, the orientation about the implementation was given to the students as well as project supervisors where the course planning, review process, and expectation from the project were discussed. A total of 17 heterogeneous project groups were formed by the students with a maximum of 04 students in a group and based on the project groups' area of interest the respective supervisor was allotted to the group.

The student preference sheet is shown in Figure 1. The students in a group of not more than 04 were work under the guidance of the project supervisor on the project undertaken by them. The project phases consist of,

\section{Project Phase I}

- To search and select an appropriate topic for capstone project work, in view of innovations, new products, and solutions to long-standing problems.

- A comprehensive and up-to-date literature survey of study.

- Prepare and refine the project proposal to the point where the student should demonstrate that it is worthy of the undertaking and should be completed in the time available.

- Apply appropriate methodology to solve critical engineering problems.

- Prepare a well-defined project plan with a budget linked to project activities and outcomes.
- Design of components, equipment, product, and process that will fulfill the requirements.

\section{Project Phase II}

- Use modern engineering tools to optimize the design or process.

- Experimental authentication of principles used in applications related to Engineering.

- Develop the product or process by using a suitable manufacturing and fabrication method.

- Software development for a particular application.

- Test the product or process in different aspects by applying several boundary conditions.

- Prepare project report completed in all corners.

- Presentation/Demonstration of a project at various platforms.

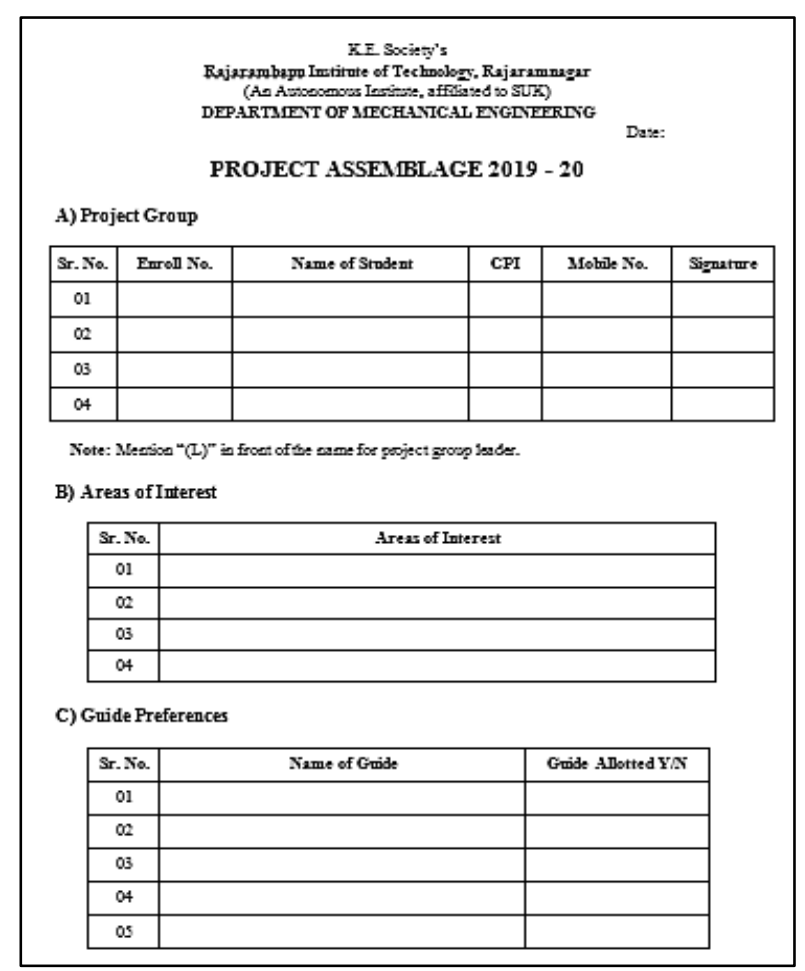

Figure 1. Student Preference Template for Supervisor Allotment

The objective of the course is to prepare the students to examine the real-life/industrial problems from all aspects of design or process or phenomenon, to encourage the process of problem-solving through independent thinking and working, and to expose the students to industry. Also, the capstone project provides an opportunity to integrate and apply knowledge from different disciplines to conduct an open-ended engineering project in a team. Capstone projects can effectively consolidate and further develop generic skills in a disciplinary and interdisciplinary context. Considering the objectives of the capstone project the course learning outcomes are defined as below; 


\section{Phase I:}

Upon successful completion of the capstone project, the student is expected to be able to:

1. Recognize the problem area and convert an openended need statement into a statement of work or a set of design specifications by finding the literature gap.

2. Identify the major project task, decompose the task into subtasks, prioritizes subtasks, and prepare a timeline and milestones by which progress may be assessed.

3. Select and apply the appropriate design of experiments, experimental setup, models, or simulation technique for the project task.

4. Collaborates with team members of diverse backgrounds and perspectives to achieve a common goal.

5. Produce usable documents of record regarding the design process and design state and communicate effectively.

\section{Phase II:}

6. Select and apply the appropriate design of experiments, experimental setup, models, or simulation technique for the project task.

7. Fabricate project or experimental setup, or model and analyze the output of models/simulations to provide information for decisions

8. Perform feasibility analysis and uses results to choose candidate solutions and evaluates the quality of solutions to select the best one

9. Collaborates with team members of diverse backgrounds and perspectives to achieve a common goal.

10. Write a technical report and communicate effectively.

The detailed project plan with an evaluation scheme for Phase I and Phase II is provided in Table 2. Initially, it was shared with the student and faculty for the effective planning of the project work. To assess the student skills and work the interdisciplinary committee has been formed under the guidance of the Head of the department. The committee consists of a team of 5 project supervisors headed by the group chairman (senior faculty).

The performance of each student was assessed individually together with the team's overall performance by the project supervisor, Group chairman, and committee by using the evaluation rubrics. The sample evaluation rubric of the best project is provided in Table 3 (Sushma Kulkarni et al. 2020). The project committee should consist of at least four academic staff with a project supervisor. The average scores of all supervisors for each rubric are combined to get a weighted average grade point. In developing the rubrics, an important consideration was that the rubrics would be used by the course coordinator, as well as the faculty supervisor for the individual student project teams. The rubrics must provide enough description for each criterion and level of achievement that different evaluators would provide similar evaluations for the same assessment task.

Table 2. Project Plan with the Evaluation Scheme

\begin{tabular}{|c|c|c|c|}
\hline $\begin{array}{l}\text { Sr. } \\
\text { No. }\end{array}$ & Activity Description & $\begin{array}{l}\text { Scheduled } \\
\text { Date }\end{array}$ & Evaluation \\
\hline \multicolumn{4}{|c|}{ Phase I } \\
\hline 1. & $\begin{array}{ll}\begin{array}{l}\text { Project } \\
\text { assemblage }\end{array} & \text { group } \\
\end{array}$ & $\begin{array}{l}1^{\text {st }} \text { week of } \\
\text { June }\end{array}$ & \\
\hline 2. & $\begin{array}{l}\text { Allocation of Project } \\
\text { Supervisors }\end{array}$ & $\begin{array}{l}2^{\text {nd }} \text { week of } \\
\text { June }\end{array}$ & \\
\hline 3. & $\begin{array}{l}\text { Problem Identification } \\
\text { Literature survey, Field } \\
\text { survey }\end{array}$ & $\begin{array}{l}3^{\text {rd }}-4^{\text {th }} \text { week } \\
\text { of June }\end{array}$ & \\
\hline 4. & $\begin{array}{l}\text { Methodology of } \\
\text { Project, Project plan, } \\
\text { Resources requirement, } \\
\text { Cost estimation }\end{array}$ & Month of July & \\
\hline 5. & Synopsis Presentation & $\begin{array}{l}2^{\text {nd }} \text { week of } \\
\text { August }\end{array}$ & $\begin{array}{l}50 \% \\
\text { Weightage }\end{array}$ \\
\hline 6. & $\begin{array}{l}\text { Submission of final } \\
\text { Synopsis approved by } \\
\text { the committee }\end{array}$ & $\begin{array}{l}3^{\text {rd }} \text { week of } \\
\text { August }\end{array}$ & \\
\hline 7. & $\begin{array}{l}\text { Design Approach/ } \\
\text { Phase I }\end{array}$ & $\begin{array}{l}\text { Month of } \\
\text { September }\end{array}$ & \\
\hline 8. & Review I & $\begin{array}{l}1^{\text {st }} \text { week of } \\
\text { October }\end{array}$ & $\begin{array}{l}50 \% \\
\text { Weightage }\end{array}$ \\
\hline 9. & $\begin{array}{l}\text { Submission of Review I } \\
\text { Project report }\end{array}$ & $\begin{array}{l}2^{\text {nd }} \text { week of } \\
\text { October }\end{array}$ & \\
\hline \multicolumn{4}{|c|}{ Phase II } \\
\hline 10. & $\begin{array}{lr}\text { Design } & \text { and } \\
\text { development } & \text { of } \\
\text { Product/Test } & \text { Setup/ } \\
\text { Model } & \end{array}$ & $\begin{array}{l}\text { Month of } \\
\text { January and } \\
\text { February }\end{array}$ & \\
\hline 11. & Review II Presentations & $\begin{array}{l}4^{\text {th }} \text { week of } \\
\text { February }\end{array}$ & $\begin{array}{l}25 \% \\
\text { Weightage }\end{array}$ \\
\hline 12. & $\begin{array}{llr}\text { Compliance } & \text { with the } \\
\text { suggestions } & \text { given in } \\
\text { review II } & & \end{array}$ & $\begin{array}{l}\text { Month } \\
\text { March }\end{array}$ & \\
\hline 13. & $\begin{array}{l}\text { Testing and } \text { Result } \\
\text { analysis } \\
\text { Report Writing }\end{array}$ & $\begin{array}{l}\text { Month of } \\
\text { March and } \\
\text { April }\end{array}$ & \\
\hline 14. & $\begin{array}{l}\text { Review III } \\
\text { Presentations (Quantum } \\
\text { project exhibition) }\end{array}$ & $\begin{array}{l}3^{\text {rd }} \text { week of } \\
\text { April }\end{array}$ & $\begin{array}{l}25 \% \\
\text { Weightage }\end{array}$ \\
\hline 15. & $\begin{array}{lr}\text { End } & \text { semester } \\
\text { Examination } & \text { (Expert } \\
\text { from industry) } & \\
\end{array}$ & Month of May & $\begin{array}{l}50 \% \\
\text { Weightage }\end{array}$ \\
\hline 16. & Report Submission & $\begin{array}{l}\text { Before the } 4^{\text {th }} \\
\text { week of May }\end{array}$ & \\
\hline
\end{tabular}

The students were encouraged to select the advanced topics for project work based on their expertise in academics and professional experience and based on their future career options. Students are also motivated to connect their projects with community issues or problems so that students can apply their learning in actual practice and it 
Table 3. Sample Evaluation Rubrics for Best Project

\begin{tabular}{|c|c|c|c|c|}
\hline \multirow[b]{2}{*}{ Criteria } & \multicolumn{4}{|c|}{ Grade Points } \\
\hline & $\begin{array}{l}\text { Excellent } \\
(4 \text { Points }) \\
\end{array}$ & \begin{tabular}{c|} 
Good \\
(3 Points) \\
\end{tabular} & $\begin{array}{c}\text { Average } \\
\text { (2 Points) } \\
\end{array}$ & $\begin{array}{l}\text { Unacceptable } \\
\text { (1 Point) }\end{array}$ \\
\hline $\begin{array}{l}\text { Innovation/Creati } \\
\text { vity in the project }\end{array}$ & $\begin{array}{lr}\begin{array}{l}\text { Project is unique, } \\
\text { concepts } \\
\text { Innovative work } \\
\text { research value }\end{array} \\
\end{array}$ & $\begin{array}{l}\text { New concepts used; } \\
\text { Minor Innovative } \\
\text { work }\end{array}$ & $\begin{array}{l}\text { Superficial usage of new } \\
\text { concepts but lacks } \\
\text { innovation }\end{array}$ & $\begin{array}{l}\text { Used basic concepts. } \\
\text { Fair level of Creativity. }\end{array}$ \\
\hline $\begin{array}{l}\text { Approach/Method } \\
\text { ology selected for } \\
\text { solution }\end{array}$ & $\begin{array}{l}\text { Very Good } \\
\text { Understanding of } \\
\text { methodology selected for } \\
\text { solution/experimentation } \\
\text { with justification }\end{array}$ & $\begin{array}{l}\text { Good Understanding } \\
\text { of methodology } \\
\text { selected for solution } \\
\text { /experimentation }\end{array}$ & $\begin{array}{lr}\text { Average } & \\
\text { Understanding } & \text { of } \\
\text { methodology } & \text { selected } \\
\text { for } & \text { solution } \\
\text { /experimentation } & \end{array}$ & $\begin{array}{l}\text { No clear understanding } \\
\text { of the methodology } \\
\text { selected for solution } \\
\text { /experimentation. } \\
\text { Unable to explain }\end{array}$ \\
\hline $\begin{array}{l}\text { Accomplishment } \\
\text { of Objectives }\end{array}$ & $\begin{array}{l}\text { All defined objectives are } \\
\text { achieved with excellent } \\
\text { work. }\end{array}$ & $\begin{array}{l}\text { All defined objectives } \\
\text { are achieved with } \\
\text { conventional work. }\end{array}$ & $\begin{array}{l}\text { Some of the defined } \\
\text { objectives are achieved. }\end{array}$ & $\begin{array}{l}\text { Defined objectives are } \\
\text { not achieved. }\end{array}$ \\
\hline $\begin{array}{l}\text { Effectiveness to } \\
\text { society/Industry }\end{array}$ & $\begin{array}{l}\text { Extremely useful to } \\
\text { society/industry. }\end{array}$ & $\begin{array}{l}\text { Moderately useful to } \\
\text { society/industry }\end{array}$ & $\begin{array}{l}\text { Somewhat useful to } \\
\text { society/industry }\end{array}$ & $\begin{array}{l}\text { Not at all useful to } \\
\text { society/ industry }\end{array}$ \\
\hline $\begin{array}{l}\text { Presentation and } \\
\text { Communication } \\
\text { (QA) }\end{array}$ & $\begin{array}{l}\text { Excellent organization \& } \\
\text { preparation, Handle } \\
\text { difficult questions with } \\
\text { ease \& confidence, } \\
\text { Illustrative explanation }\end{array}$ & $\begin{array}{l}\text { Good organization \& } \\
\text { preparation. } \\
\text { Answer most } \\
\text { questions correctly } \\
\text { and concisely }\end{array}$ & $\begin{array}{l}\text { Basic organization and } \\
\text { preparation. } \\
\text { Answer most questions } \\
\text { correctly, Need } \\
\text { clarification sometimes }\end{array}$ & $\begin{array}{lr}\text { Bare organization and } \\
\text { preparation. Answer at } \\
\text { least one } \\
\begin{array}{l}\text { correctly, } \\
\text { clarification }\end{array} \\
\end{array}$ \\
\hline
\end{tabular}

will integrate the practical learning experience. As a part to enhance the quality of student projects the facilities are made available in the college campus for $24 \mathrm{hrs}$. The separate project space was developed with recent and advanced tools used for prototype development such as a 3D printer, lathe machines, pipe bending, welding machines, mechanical tool kits, etc. Also, 12 mechanical engineering laboratories were updated with recent equipment considering the project requirement. Figure 2 shows the students working in the project laboratory.

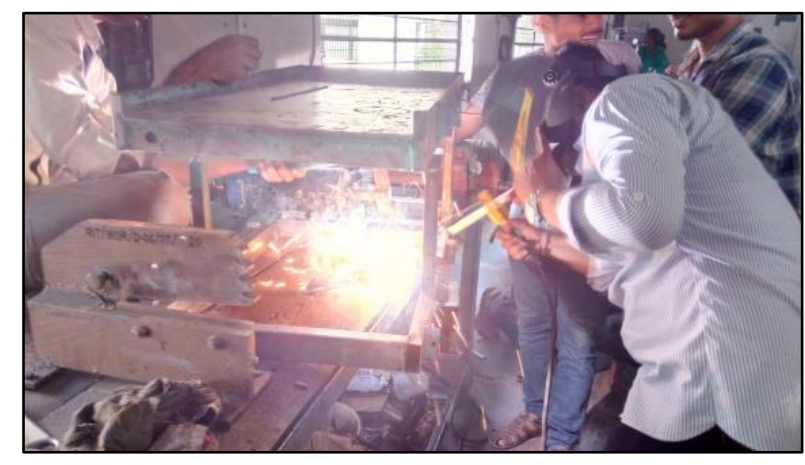

Figure 2. Students working in Project Laboratory

\section{Result and Discussion:}

The twelve credit capstone project course was divided into two modules and using a strategic plan all the activities of the capstone project were performed. More than 72 students and 18 supervisors were continuously engaged in the activity throughout the academic year. Around 17 heterogeneous student groups were formed by taking the choices from the student so that students will get the chance to work in an interesting area with the expert supervisor.
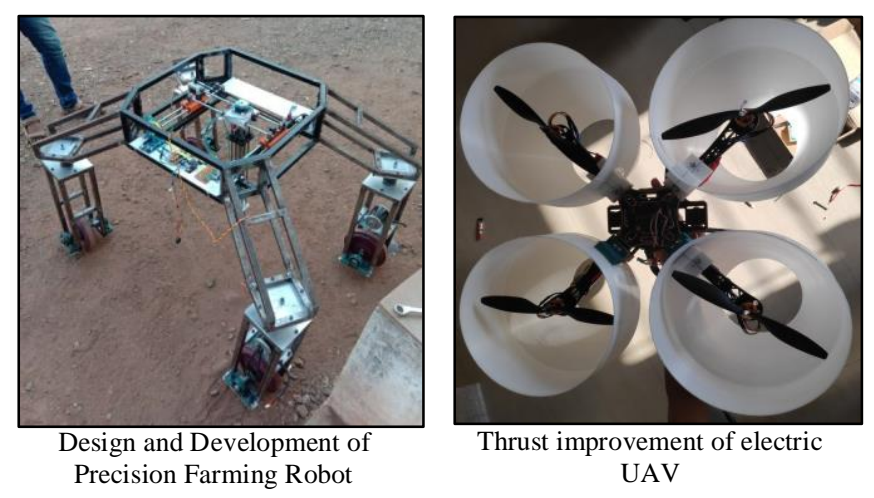

Thrust improvement of electric UAV
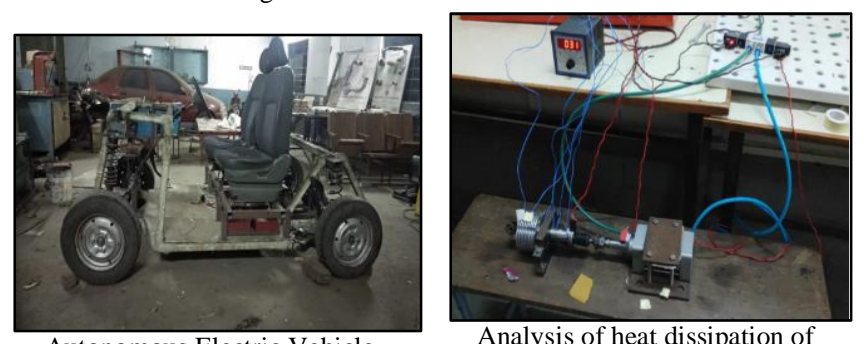

Analysis of heat dissipation of hydraulic shock absorber
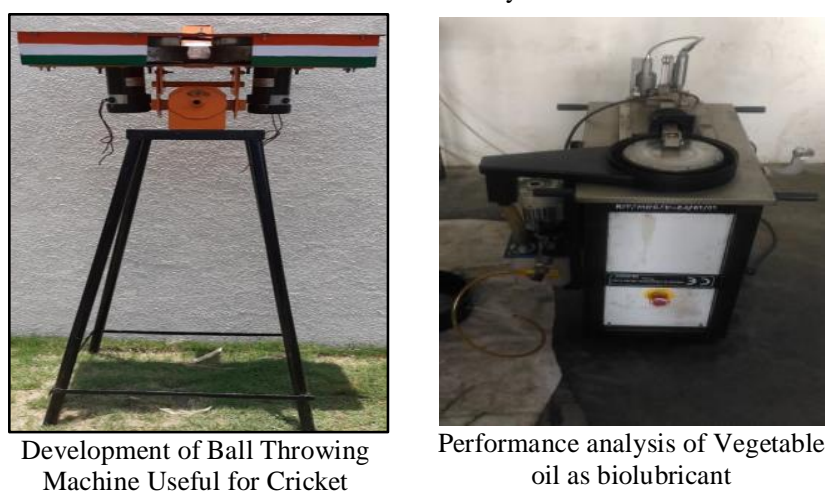

Performance analysis of Vegetable oil as biolubricant

Figure 3. Sample Project Developed by the Students 
In order to enhance the quality and to encourage the student the approaches such as In house seed funding, Project competition, industrial visits, and expert lectures were initiated. Around 2 Lakh rupees in-house seed funding was provided to the student project group every year with the purpose to create the research culture in the college campus and to enhance the student representation at national and international levels. As a result of this initiative, the students have filed more than 08 patents and also published more than 10 research papers in the reputed national/ international journals/conferences.

With the intent to provide all the necessary facilities in the college campus, the special project space was created for product development with all the required mechanical tools and equipment. The total investment was around 20 lakh for the project laboratory. In addition to that, the existing mechanical laboratories were equipped with recent equipment. The sample projects developed by the student groups were presented in Figure 3.
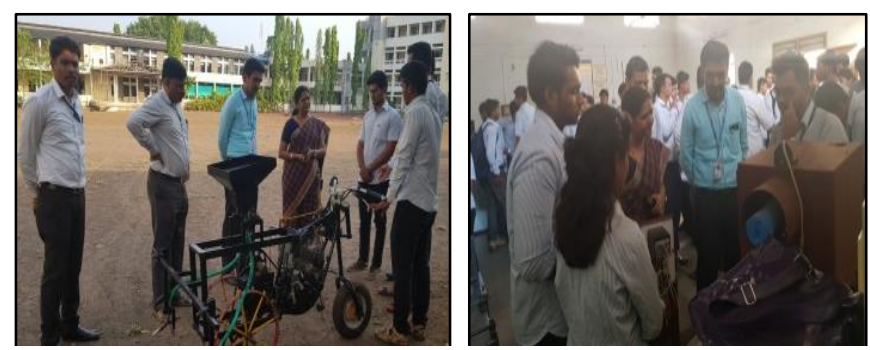

Figure 4. Glimpse of project exhibition

The project Exhibition (Quantum) has been arranged every year to create a competitive scenario in the student project groups. The industrial experts are called for the student evaluation and the best three projects are identified by considering the learning outcomes, evaluation rubrics, and innovativeness. The glimpses of the project exhibition are shown in Figure 4.

The attainment of the course outcomes (CO) also shows an increment trend in student learning. From the student feedback, it is also observed that the students have developed their technical as well as soft skills. The student learnings are continuously assessed using assessment rubrics. The assessment rubrics are mapped with course outcomes, the sample mapping is shown in Table 4, and using commercial software IonCudos the threshold-based attainment is calculated using the following equation,

$$
\begin{aligned}
& \mathrm{DC}=\frac{\frac{1}{n} \sum_{i=1}^{n} X_{i}}{M_{\max }} \times 100 \\
& \mathrm{IDC}=\frac{\sum_{i=0 j=0}^{n, m}\left(Y_{i} Z_{j}\right)}{n \times m} \times 100 \\
& \mathrm{CA}=(0.7 \mathrm{DC}+0.3 \mathrm{IDC})
\end{aligned}
$$

Where,

$\mathrm{DC}=$ Average direct $\mathrm{CO}$ attainment $(\%)$

IDC = Average Indirect $\mathrm{CO}$ attainment (\%)

$\mathrm{CA}=\mathrm{CO}$ attainment $(\%)$

$\mathrm{n} \quad=$ the total number of students

$\mathrm{m} \quad=$ Maximum rating allotted for respective $\mathrm{CO}$

$\mathrm{x}_{\mathrm{i}} \quad=$ the marks obtained by each student for respective $\mathrm{CO}$

$\mathrm{Y}_{\mathrm{i}} \quad=$ Rating given by the individual student to $\mathrm{CO}$ level

$\mathrm{Z}_{\mathrm{i}} \quad=$ Number of students rated the respective $\mathrm{CO}$ level

$\mathrm{M}_{\max } \quad=$ Maximum marks allotted to respective $\mathrm{CO}$

Where indirect attainment is obtained by conducting a course end survey based on CO's.

Table 4. Sample mapping of evaluation rubrics with CO

\begin{tabular}{|c|c|c|c|c|c|}
\hline CO & $\begin{array}{c}\text { Understa } \\
\text { nding of } \\
\text { project } \\
\text { Problem }\end{array}$ & $\begin{array}{c}\text { Approach } \\
\text { or } \\
\text { Methodolo } \\
\text { gy selected } \\
\text { for } \\
\text { solution }\end{array}$ & $\begin{array}{c}\text { Work } \\
\text { complet } \\
\text { ed as } \\
\text { per plan } \\
\text { given in } \\
\text { synopsis }\end{array}$ & $\begin{array}{c}\text { Design of } \\
\text { project/ DOE } \\
\text { completed and } \\
\text { ready for } \\
\text { manufacturin } \\
\text { g/experimenta } \\
\text { tion }\end{array}$ & $\begin{array}{c}\text { Soft skills/ } \\
\text { working as } \\
\text { a team } \\
\text { member }\end{array}$ \\
\hline CO1 & $\sqrt{ }$ & & & & \\
\hline CO2 & & $\sqrt{ }$ & $\sqrt{ }$ & & \\
\hline CO3 & & $\sqrt{ }$ & & $\sqrt{ }$ & \\
\hline CO4 & & & & & $\sqrt{ }$ \\
\hline CO5 & & & & & $\sqrt{ }$ \\
\hline
\end{tabular}

The threshold-based course learning attainment of project phase-I is shown in Figure 5 and project phase II is shown in Figure 6. From the $\mathrm{CO}$ attainment, it is observed that for phase I all the CO's were attained more than $75 \%$ and for phase II all the CO's were attained more than $80 \%$. The $\mathrm{CO} 2, \mathrm{CO} 3, \mathrm{CO} 5$, and $\mathrm{CO} 9$ were observed slightly lower side as compared to other CO's. Based on the attainment it is observed that students need more guidance for the project planning, design stage, and technical report writing.

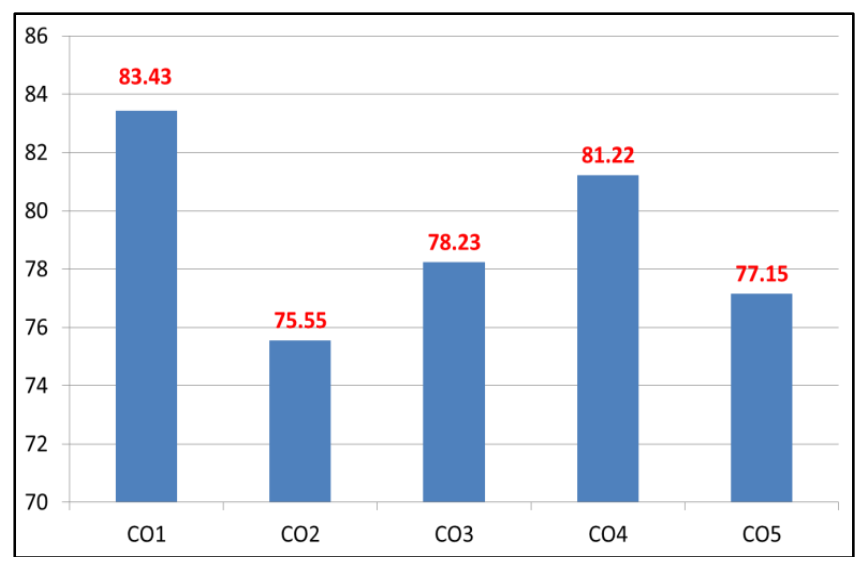

Figure 5. CO Attainment of Phase I 


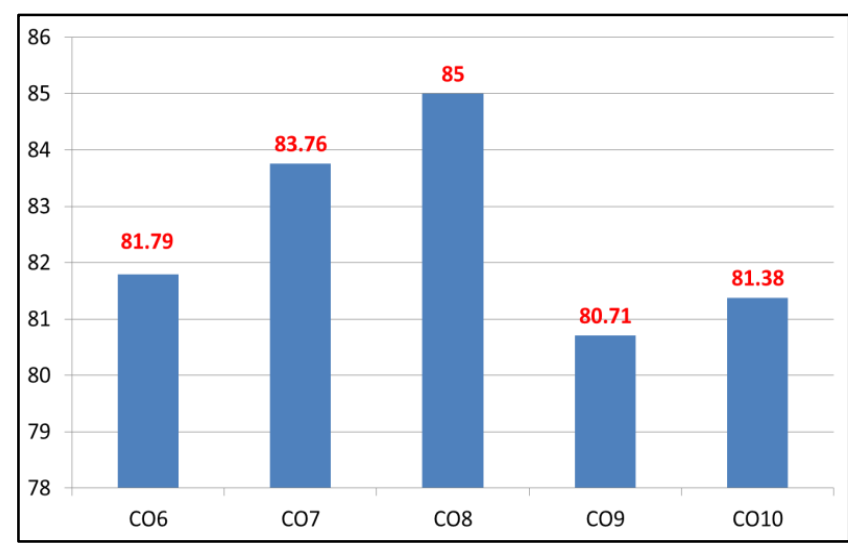

Figure 6. CO Attainment of Phase II

The Program Outcome (PO) attainment is calculated considering the attainment of $\mathrm{CO}$ which is mapped to corresponding PO's. The attainment of the program outcome for the capstone project course is presented in Figure 7. All the POs were attained more than $75 \%$ which above the target value.

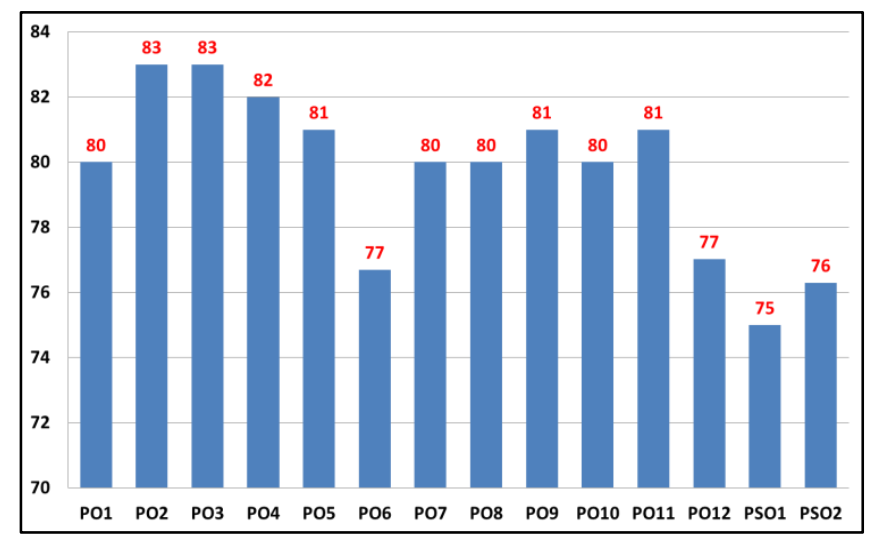

Figure 7. PO attainment for Capstone Project Course

\section{Conclusion}

The aim of the capstone project course is to nurture and encourage the student's practical skills, teamwork, communication, and project management skills, and social awareness. Around 72 students and 18 faculties were engaged in the activity and filed more than 8 patents and presented 10 papers in national and international conferences/journals. The student involvement in the project was very good with a high level of enthusiasm and commitment throughout the project development. To enhance the quality of the capstone project, Institute has introduced various initiatives such as In house seed funding, developing project space, updating mechanical laboratories, support for patent and paper publications, organizing project competition, planning systematic reviews with an expert committee, preparation of evaluation rubrics, etc. The results of the implementation were measured by calculating the $\mathrm{CO}$ and $\mathrm{PO}$ attainment using commercial software IonCudos. The attainment results show that all the learning outcomes were achieved the expected value. The attainment analysis indicates to refocus on student skills such as project planning, teamwork, and technical report writing, etc. The student feedback indicates a moderate to a high level of satisfaction with the new project initiatives.

\section{References}

Deepamala, N., and Shobha, G. (2018). Effective approach in making capstone project a holistic learning experience to students of undergraduate computer science engineering program. Journal of Technology and Science Education, 8(4), 420-438. https://doi.org/10.3926/jotse.427

Jon M. Duff, Thomas E. Schildgen, 2005 Establishing Outcomes for Senior Capstone Projects In Industrial Technology, Proceedings of the 2005 American Society for Engineering Education Annual Conference \& Exposition

Kala Meah, Donald Hake II, and Stephen Drew Wilkerson, (2020) A Multidisciplinary Capstone Design Project to Satisfy ABET Student Outcomes, Hindawi Education Research International Article ID 9563782, https://doi.org/10.1155/2020/9563782.

Jacqueline Stagner and Jennifer Johrendt, (2014) Mechanical Engineering Capstone Design Course - CEAB Accreditation Outcomes Assessment, Proc. 2014 Canadian Engineering Education Association (CEEA14) Conf.

Manankil-Rankin, Louela; Lunyk Child, Ola; Chen, Ruth; Martin, Lynn; and Bentley Poole, Lynda (2016) "A Capstone Project: A way to Integrate Knowledge and Empower Students to Become Change Agents in the Practice Setting.," Quality Advancement in

Nursing Education - Avancées en formation infirmière: Vol. 2: Iss. 1, Article 6.

Mohamed A. Omar (2014) Design and Implementation of a Capstone Course to Satisfy the Industry Needs of Virtual Product Development and ABET Engineering Criteria, Hindawi Publishing Corporation Education Research International, Article ID 578148, http://dx.doi.org/10.1155/2014/578148

Mosher, Gretchen A., "Enhancing Team-Based Senior Capstone Projects: Opportunities and Challenges" (2014). 2014 ASEE North Midwest Section Conference. 1.

Rajendra Pawar, Sushma Kulkarni, Sachin Patil, Project Based Learning: An Innovative Approach for Integrating 21st Century Skills, Journal of Engineering Education Transformations, Volume 33, No. 4, 58-63.

Rajendra Pawar, Rajanikant Metri, Supriya Sawant, Sushma Kulkarni (2020) Evolving Product Development Skills Through Group Based Activity Instructions in Engineering Exploration Course, Procedia Computer Science 172, 314-323.

S. Howe, L. Rosenbauer, and S. Poulos, "The 2015 capstone design survey results: current practices and changes over time," International Journal of Engineering Education, vol. 33, no. 5, pp. 1393-1421, 2017. DOI: https://doi.org/10.17483/2368-6669.1060

Shekar Viswanathan, 2017, Implementation Of Effective Capstone Projects In Undergraduate Manufacturing Design 
Engineering Program, American Journal of Engineering Education, Volume 8, Number 1, pp 45-60.

Sushma Kulkarni, SachinPatil, and Rajendra Pawar (2020) Adoption of the Conceive-Design-ImplementOperate approach to the Third Year Project in a team-based design build environment, Procedia Computer Science 172, 559-567

Tien D.T.K., Mohyi M.H.H. (2016) Assessment in Mechanical Engineering Capstone Project: The Case of Taylor's University. In: Tang S., Logonnathan L. (eds) Assessment for Learning Within and Beyond the Classroom. Springer, Singapore. http://doi-org443.webvpn.fjmu.edu.cn/10.1007/978-981-10-0908-2_24. 